\title{
Mammalian Nicotinic Receptors with $\alpha 7$ Subunits That Slowly Desensitize and Rapidly Recover from $\alpha$-Bungarotoxin Blockade
}

\author{
Javier Cuevas and Darwin K. Berg \\ Department of Biology, University of California, San Diego, La Jolla, California 92093-0357
}

One of the most abundant nicotinic receptors in the nervous system is a species that contains the $\alpha 7$ gene product, rapidly desensitizes, and binds $\alpha$-bungarotoxin with great affinity. The receptor has a high relative permeability to calcium and performs a variety of functions including presynaptic modulation of transmitter release and postsynaptic generation of synaptic currents. Fast excitatory transmission in mammalian intracardiac ganglia is mediated primarily by nicotinic receptors, and although intracardiac ganglion neurons express the $\alpha 7$ gene, no toxin-sensitive response has been detected previously in them. We report here that whole-cell patch-clamp recordings from freshly dissociated intracardiac ganglion neurons reveal a nicotinic response that desensitizes slowly and is blocked by $\alpha$-bungarotoxin in a rapidly reversible manner. The only rat gene previously thought capable of forming such receptors was $\alpha 9$, but no evidence suggests that the $\alpha 9$ gene is expressed in neurons. We find that reverse transcription (RT)-PCR detects $\alpha 7$ but not $\alpha 9$ mRNA in the ganglia. In addition, the pharmacology of the nicotinic response is typical of $\alpha 7$-containing receptors but differs in several respects from that expected for $\alpha 9$. Binding experiments with immunotethered receptors identifies a ganglionic species that contains the $\alpha 7$ gene product. Moreover, intracellular perfusion of the cells with an anti- $\alpha 7$ monoclonal antibody specifically reduces the amplitude of the toxin-sensitive response. The results indicate that $\alpha 7$ containing receptors are responsible for the slowly desensitizing, toxin-reversible response and suggest that the receptors are modified in cell-specific ways to influence their functional properties.

Key words: nicotinic; receptors; acetylcholine; intracardiac ganglion; neuronal; $\alpha 7$; $\alpha$-bungarotoxin; patch clamp
The nicotinic acetylcholine receptor (AChR) $\alpha 7$ gene is widely expressed in the nervous system and accounts for the most abundant species of neuronal AChR in both chick and rat (Marks et al., 1986; Couturier et al., 1990; Schoepfer et al., 1990; Anand et al., 1993b; Chen and Patrick, 1997; Conroy and Berg, 1998). When heterologously expressed in Xenopus oocytes, $\alpha 7$ protein assembles into homopentameric ligand-gated ion channels that are cation-selective, rapidly desensitize, and bind $\alpha$-bungarotoxin ( $\alpha$ Bgt) with high affinity (Couturier et al., 1990; Bertrand et al., 1993; Seguela et al., 1993). Responses from native AChRs containing the $\alpha 7$ gene product ( $\alpha 7$-AChRs) have been reported in several systems and have always been found to be similar to those of the homopentamer in oocytes; namely, they rapidly desensitize and are blocked by $\alpha$ Bgt in a long-lasting manner (Zorumski et al., 1992; Alkondon and Albuquerque, 1993; Zhang et al., 1994).

Native $\alpha 7$-AChRs are likely to serve a number of physiological roles. Recent evidence indicates they can act presynaptically to modulate neurotransmitter release (McGehee et al., 1995; Gray et al., 1996; Coggan et al., 1997) and can function at extra- or perisynaptic sites on neurons to generate synaptic currents as well (Zhang et al., 1996; Ullian et al., 1997). Genetic studies have linked the receptors to a form of schizophrenia (Freedman et al.,

\footnotetext{
Received June 8, 1998; revised Sept. 18, 1998; accepted Oct. 5, 1998.

This work was supported by the National Institutes of Health Grants NS 12601 and 35469 and by TRDRP Grant RT65-0050. J.C. is a University of California President's Fellow. We thank Dr. Jon Lindstrom (University of Pennsylvania, Philadelphia, PA) for generously supplying monoclonal antibodies.

Correspondence should be addressed to Dr. Darwin K. Berg, Department of Biology, 0357, University of California, San Diego, 9500 Gilman Drive, La Jolla, CA 92093-0357.

Dr. Cuevas's present address: Department of Pharmacology and Therapeutics, University of South Florida College of Medicine, Tampa, FL 33612-4799.

Copyright (C) 1998 Society for Neuroscience $\quad 0270-6474 / 98 / 1810335-10 \$ 05.00 / 0$
}

1997). Cell culture analysis has suggested the receptors may be important for early developmental events because they can be found on growing neurites (Pugh and Berg, 1994; Fu and Liu, 1997). This diversity of function raises the question of whether the properties of $\alpha 7$-AChRs vary with cellular location to accommodate site-specific job requirements.

Most puzzling has been the repeated finding of $\alpha \mathrm{Bgt}$ binding on neurons with no apparent $\alpha$ Bgt-sensitive response (Duggan et al., 1976; Carbonetto et al., 1978; Betz, 1981; Lipton et al., 1987; Sucher et al., 1990; Zhang and Feltz, 1990; Sargent and Garrett, 1995). This has frequently been the finding with mammalian autonomic neurons (Nurse and O'Lague, 1975; Brown and Fumagalli, 1977; Ascher et al., 1979; Mandelzys et al., 1995). Other than $\alpha 7$, the only known genes that produce $\alpha$ Bgt-binding receptors are the muscle $\alpha 1$ and either the $\alpha 9$ in mammals or the $\alpha 8$ in chick. Neither the $\alpha 1$ nor the $\alpha 9$ genes are expressed in neurons (Elgoyhen et al., 1994; Karlin and Akabas, 1996). Although the chick $\alpha 8$ is expressed in neurons, it either coassembles with $\alpha 7$ subunits to produce heteromers or self-assembles to produce $\alpha 8$-containing homomers (Schoepfer et al., 1990; Anand et al., 1993a), and both are capable of $\alpha$ Bgt-sensitive responses when expressed in oocytes (Gerzanich et al., 1994).

An interesting system to explore the nature of $\alpha 7-\mathrm{AChR}$ responses is provided by mammalian intracardiac ganglia. The ganglia mediate efferent parasympathetic input to the heart and are thought to exert local regulation over cardiac function by integrating information from efferent and afferent pathways of both parasympathetic and sympathetic origin (Moravec and Moravec, 1987; Gagliardi et al., 1988). Extrinsic and intrinsic innervation of the ganglia is predominantly cholinergic, with activation of AChRs resulting in fast excitatory transmission 
(Seabrook et al., 1990). Rat intracardiac ganglion neurons apparently express multiple AChR subtypes, and the combination of subtypes expressed varies among cells (Poth et al., 1997). Although many of the neurons express the $\alpha 7$ gene (Poth et al., 1997), no $\alpha$ Bgt-sensitive responses have been detected previously in the cells (Selyanko and Skok, 1992).

We have used whole-cell patch-clamp recording, together with rapid application of agonist, to examine the nicotinic ACh responses of dissociated rat intracardiac ganglion neurons. The neurons display a slowly desensitizing response that is blocked by $\alpha \mathrm{Bgt}$ in a rapidly reversible manner. Pharmacological analysis, reverse transcription (RT)-PCR, immunoprecipitation, and intracellular dialysis with subunit-specific monoclonal antibodies (mAbs) are each consistent with the conclusion that $\alpha 7$-AChRs produce the response. The implication is that $\alpha 7-\mathrm{AChRs}$ can be modified or regulated to display different properties in different environments. If $\alpha 7-\mathrm{AChRs}$ in intracardiac ganglion neurons retain the feature of having a high relative permeability to calcium, their ability to sustain long-duration currents in this case is likely to empower them with a major role in ganglionic signaling and regulation of cardiac function.

\section{MATERIALS AND METHODS}

Tissue preparation. Neurons from neonatal rat intracardiac ganglia were isolated and maintained as described previously (Cuevas and Adams, 1994). Briefly, to obtain intracardiac ganglion neurons, we killed postnatal day 3 (P3)-P7 rats by decapitation. The hearts were excised and placed in a saline solution containing (in $\mathrm{mM}$ ): $140 \mathrm{NaCl}, 3 \mathrm{KCl}, 2.5$ $\mathrm{CaCl}_{2}, 0.6 \mathrm{MgCl}_{2}, 7.7$ glucose, and 10 histidine, $\mathrm{pH} 7.2$ with $\mathrm{NaOH}$. The atria were separated and incubated in saline solution containing collagenase ( $1 \mathrm{mg} / \mathrm{ml}$; Type $1 \mathrm{~A}$; Worthington, Freehold, $\mathrm{NJ}$ ) at $37^{\circ} \mathrm{C}$ for 60 min. After enzymatic treatment, clusters of ganglia were dissected from the epicardial ganglion plexus and dispersed by titration in a high glucose culture medium (DMEM; Life Technologies, Gaithersburg, MD) with $10 \%$ fetal calf serum, 100 units $/ \mathrm{ml}$ penicillin, and $0.1 \mathrm{mg} / \mathrm{ml}$ streptomycin. The dissociated neurons were then plated on glass coverslips coated with laminin, incubated at $37^{\circ} \mathrm{C}$ under a $95 \%$ air $/ 5 \% \quad \mathrm{CO}_{2}$ atmosphere, and examined 36-72 hr later.

Chick ciliary ganglion neurons were dissociated from 14-15 d embryos as described previously (Margiotta and Gurantz, 1989). Briefly, the ganglia were dissected from the embryo, incubated with $1 \mathrm{mg} / \mathrm{ml}$ collagenase for $30 \mathrm{~min}$ at $37^{\circ} \mathrm{C}$, and transferred to culture medium made up of Eagle's Minimal Essential Medium (Life Technologies) supplemented with $3 \%(\mathrm{v} / \mathrm{v})$ embryonic eye extract (Nishi and Berg, 1981). The cells were dispersed by trituration, plated on a substratum of poly-D-lysine in $35 \mathrm{~mm}$ Costar culture dishes, and examined 1-3 hr later.

Electrophysiological recordings. Neurons plated on glass coverslips were transferred to a recording chamber (volume, $0.5 \mathrm{ml}$ ) mounted on an inverted phase-contrast microscope (magnification, $400 \times$ ) that allowed isolated cells to be identified. Membrane currents in intracardiac neurons were studied under voltage-clamp mode using the whole-cell patch-clamp technique (Hamill et al., 1981). Electrical access was achieved conventionally by rupturing the membrane under the patch pipette or via the use of the perforated-patch method (Horn and Marty, 1988). Patch electrodes were pulled from thin-walled [outer diameter (o.d.), $1.5 \mathrm{~mm}$ ] borosilicate glass (Drummond Scientific, Broomall, PA) using a Sutter Instruments P-87 pipette puller (Novato, CA) and had resistances of 1-1.5 M $\Omega$. For conventional (dialyzing) whole-cell experiments, the intracellular solution contained (in $\mathrm{mm}$ ): $140 \mathrm{CsCl}, 10$ glucose, 2 EGTA, and $10 \mathrm{HEPES}, \mathrm{pH} 7.2$ with $\mathrm{CsOH}$. In some conventional whole-cell experiments, cells were dialyzed $(\geq 10 \mathrm{~min}$ ) with patch pipette solutions containing subunit-specific anti-AChR mAbs; the specificities of the mAbs have been described previously [see references in Vernallis et al. (1993); Conroy and Berg (1995)]. The intracellular solution in perforated-patch experiments contained (in mM): $75 \mathrm{~K}_{2} \mathrm{SO}_{4}, 55 \mathrm{KCl}, 5$ $\mathrm{MgSO}_{4}, 360 \mu \mathrm{g} / \mathrm{ml}$ amphoterecin B, 0.6\% DMSO, and $10 \mathrm{HEPES}, \mathrm{pH}$ 7.2 with $N$-methyl-D-glucamine. The procedures for achieving electrical access with amphoterecin B were identical to those described previously (Cuevas et al., 1997) and resulted in series resistance $\leq 3 \mathrm{M} \Omega$ after compensation $(50 \%)$.
Membrane currents were amplified and filtered $(5 \mathrm{kHz})$ using an Axopatch 200A (Axon Instruments, Foster City, CA) patch-clamp amplifier, digitized with a Digidata 1200B (Axon Instruments), and acquired (20 kHz) using Clampex 6 (Axon Instruments) on a pentium/133 M Hz computer. Peak amplitude and kinetics of agonist-evoked currents were analyzed using Clampfit 6 (Axon Instruments).

The external solution for whole-cell recordings was physiological saline solution containing (in mM): $140 \mathrm{NaCl}, 3 \mathrm{KCl}, 2.5 \mathrm{CaCl}_{2}, 1.2 \mathrm{MgCl}_{2}, 7.7$ glucose, and $10 \mathrm{HEPES}, \mathrm{pH} 7.2$ with $\mathrm{NaOH}$. Agonists and antagonists were applied via a rapid application system as reported previously (Zhang et al., 1994). Briefly, control and drug-containing solutions were delivered onto the cell soma from a linear array of glass tubes (inner diameter, $250 \mu \mathrm{m}$; o.d., $350 \mu \mathrm{m}$; Polymicro Technologies, Phoenix, AZ). Flow of solution through the individual tubes was induced by gravity feed and regulated by solenoid valves (General Valve, Fairfield, NJ). Movement of the tube array was mediated by a piezoelectric bimorph connected to a voltage generator (Burleigh, Fishers, NY). The rate of solution change expected to be observed by the cell was determined by recording the liquid junction potential change from an open patch pipette and was $<5$ msec.

Solid-phase immunoprecipitations. Solid-phase immunoprecipitation assays were conducted as described previously (Conroy and Berg, 1995). Atria from neonatal rats (4 and 14 d old) were dissected as described above, and the medial region containing the pulmonary veins and the superior and inferior vena cava was isolated. These segments were homogenized in $2 \%(\mathrm{w} / \mathrm{v})$ Triton X-100 extraction buffer and incubated at $4^{\circ} \mathrm{C}$ for $1 \mathrm{hr}$. Extracts were then centrifuged at $17,000 \times g$ for $20 \mathrm{~min}$, and the supernatant fraction was collected. Rat brain extracts were prepared from whole brains of neonatal rats $(20 \mathrm{~d}$ old) using methods described previously (Conroy et al., 1992). Aliquots were incubated overnight at $4^{\circ} \mathrm{C}$ in microtiter wells precoated with anti- $\alpha 7 \mathrm{mAb} 319$ to immunotether AChRs containing the $\alpha 7$ gene product. Receptor binding was quantified with ${ }^{125} \mathrm{I}-\alpha \mathrm{Bgt}$. Nonspecific binding was determined by including either $1 \mu \mathrm{M}$ unlabeled $\alpha \mathrm{Bgt}$ or $1 \mathrm{mM}$ nicotine in the binding reaction with ${ }^{125} \mathrm{I}-\alpha \mathrm{Bgt}$ and was subtracted from total binding to obtain specific binding. In some experiments the anti- $\beta 2 \mathrm{mAb} 270$ and the anti- $\alpha 8 \mathrm{mAb} 308$ were used as immunotethering antibodies [for mAb specificities, see references in Vernallis et al. (1993); Conroy and Berg (1995)].

Epibatidine binding was determined using a filter binding assay (Conroy and Berg, 1995). Protein extracts ( $25 \mu$ l aliquots) were incubated in $2 \mathrm{~nm}\left[{ }^{3} \mathrm{H}\right]$ epibatidine for $2 \mathrm{hr}$ at room temperature. The reactions were then diluted with $4 \mathrm{ml}$ of wash buffer $[0.05 \%(\mathrm{w} / \mathrm{v})$ Triton X-100 in $10 \mathrm{~mm}$ Tris, $\mathrm{pH}$ 7.5], and the solution was immediately filtered through Whatman GF/B filters (Maidstone, UK) presoaked for $1 \mathrm{hr}$ in $0.5 \%$ polyethyleneimine. Filters were rinsed twice more with wash buffer and then counted by liquid scintillation (Ecoscint H; National Diagnostics, Atlanta, GA). Nonspecific binding was determined by including $1 \mathrm{~mm}$ nicotine in the binding reaction with $\left[{ }^{3} \mathrm{H}\right]$ epibatidine.

$R T-P C R$. The use of RT-PCR for detection of AChR gene expression in cultured neurons from rat intracardiac ganglia has been described previously (Poth et al., 1997). Briefly, RNA was extracted (RNeasy; Qiagen, Hilden, Germany) either from a dish of cultured intracardiac neurons containing $\sim 100$ neurons plus a number of other cell types (e.g., cardiac myocytes, Schwann cells, and fibroblasts) or from intact intracardiac ganglia and associated tissue (same as in culture preparations). RNA was reverse-transcribed in a $20 \mu \mathrm{l}$ reaction volume using a Life Technologies SuperScript Preamplification System kit. Negative controls including an RT reaction without reverse transcriptase and a PCR reaction with only water were conducted to eliminate the possibility of false positives because of contaminating cDNA. Primers for $\alpha 7$ and $\alpha 9$ transcripts were identical to those used previously [ $\alpha 7$ (Poth et al., 1997); $\alpha 9$ (Elgoyhen et al., 1994)]: $\alpha 7_{\text {(forward) }}$-GGAGTGAAGAATGTTCGTTTTCCAGATGG, $\alpha 7_{\text {(reverse) }}$-CCCTGGCTCTGCTGGTATTCTTGC, $\alpha 9_{\text {(forward) }}$-CTAATGGTGGCAGAGATCATGCCA, and $\alpha 9_{\text {(reverse) }}$-TATGATCAAGACGGTCATGACAAACACCA. They yielded product sizes of 476 and $573 \mathrm{bp}$, respectively. PCR reactions were conducted using the Life Technologies SuperScript Preamplification System kit, and the cycling parameters were five cycles of $94^{\circ} \mathrm{C}$ for $45 \mathrm{sec}, 55^{\circ} \mathrm{C}$ for $1 \mathrm{~min}$, and $72^{\circ} \mathrm{C}$ for $1.5 \mathrm{~min}$. This was followed by 30 cycles of $94^{\circ} \mathrm{C}$ for $45 \mathrm{sec}, 57^{\circ} \mathrm{C}$ for $1 \mathrm{~min}$, and $72^{\circ} \mathrm{C}$ for $1.5 \mathrm{~min}$.

Restriction digestion. A restriction digestion strategy was used to confirm the identity of PCR reaction products as being those expected for amplification of specific cDNAs. The two $\alpha 7$ primer products were gel-purified and digested with HaeII and BanII. Each of these endonucle- 
A

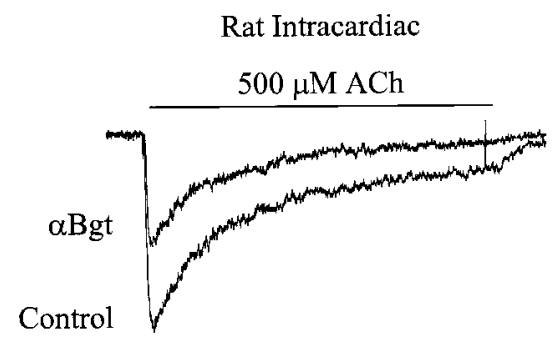

B

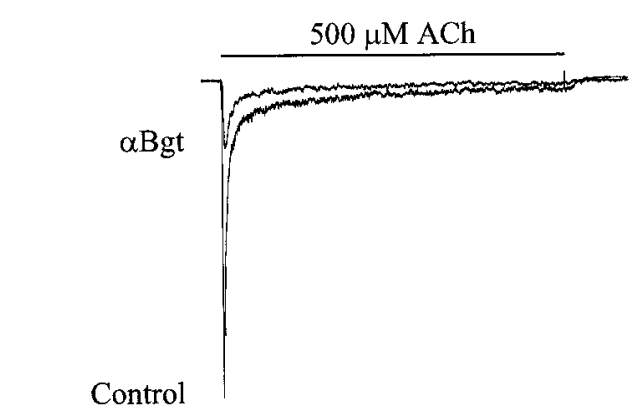

$\mathrm{C}$

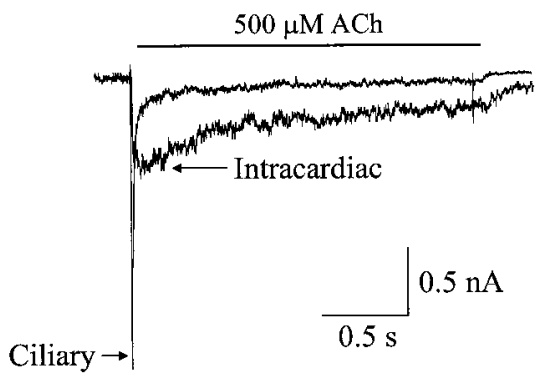

Figure 1. $\alpha$ Bgt blocks a slowly desensitizing ACh-evoked current in rat intracardiac neurons. $A, B$, Whole-cell currents evoked by rapid focal application of $500 \mu \mathrm{M}$ ACh to the soma of an isolated rat intracardiac ganglion neuron $(A)$ and an isolated chick ciliary ganglion neuron $(B)$, each voltage clamped at $-60 \mathrm{mV}$, in the absence (Control) and presence of $100 \mathrm{~nm} \alpha$ Bgt. $C$, Net $\alpha$ Bgt-sensitive ACh-evoked current, determined by subtracting the current induced by ACh in the presence of $100 \mathrm{nM} \alpha \mathrm{Bgt}$ from that recorded in the absence of the toxin for the experiments shown in $A$ and $B$.

ases targeted a different exon found in the region amplified by the primers used. Digestion of the $476 \mathrm{bp}$ fragment with both enzymes produces digestion products of 321,78 , and $77 \mathrm{bp}$. Sequence analysis of cloned PCR products was performed commercially (Retrogen, San Diego, CA).

Reagents and statistical analysis. All chemicals used were of analytical grade. Acetylcholine chloride (ACh), cytisine chloride, atropine sulfate, nicotine, and mecamylamine chloride were purchased from Sigma (St. Louis, MO). $\alpha$ Bgt was purchased from Biotoxins (St. Cloud, FL) and radioiodinated using chloramine $\mathrm{T}$ to a specific activity of $0.3-0.7 \times 10^{18}$ $\mathrm{cpm} / \mathrm{mol}$. $\left[{ }^{3} \mathrm{H}\right]$ Epibatidine $(56.5 \mathrm{Ci} / \mathrm{mmol})$ was a gift from DuPont NEN (Boston, MA), and unlabeled epibatidine was purchased from Research Biochemicals (Natick, MA). Several mAbs were generously supplied by Dr. Jon Lindstrom (University of Pennsylvania, Philadelphia, PA).

Data are presented as the mean \pm SD unless otherwise stated and were compared using paired or unpaired $t$ tests as appropriate.

\section{RESULTS}

\section{$\alpha$ Bgt-sensitive ACh-evoked currents}

Whole-cell patch-clamp techniques were used to record AChinduced currents from dissociated rat intracardiac ganglion neurons maintained 1-3 d in culture. Rapid focal application of
A

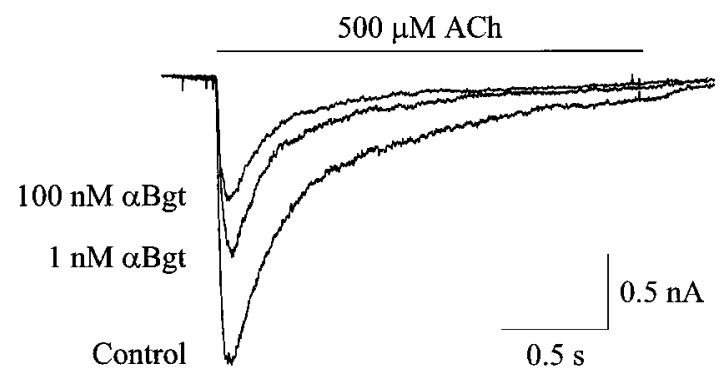

B

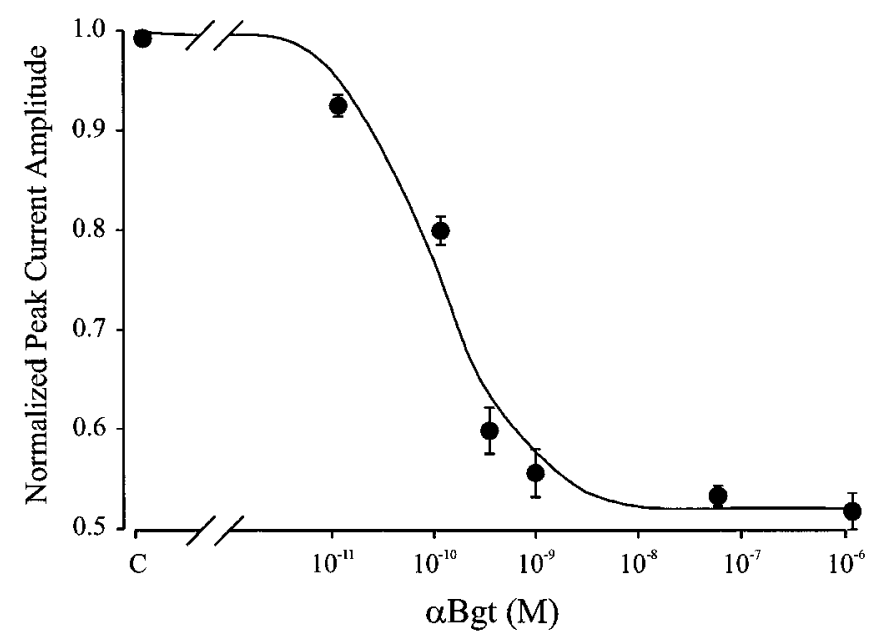

Figure 2. Dose-dependent inhibition of nicotinic ACh-evoked currents by $\alpha$ Bgt. $A$, Whole-cell currents evoked from a single neuron by focal application of $500 \mu \mathrm{M} \mathrm{ACh}$ in the absence (Control) and presence of $\alpha \mathrm{Bgt}$ (1 and $100 \mathrm{nM}$ ). The holding potential was $-60 \mathrm{mV}$. B, ACh-evoked whole-cell current amplitude at $-60 \mathrm{mV}$ normalized to values obtained from the same cells in the absence of $\alpha \mathrm{Bgt}$ and plotted as a function of $\alpha$ Bgt concentration. Data points represent mean \pm SEM $(n=7-12$ determinants; 25 neurons). The curve represents a best fit to the data using a single-site adsorption isotherm with half-maximal inhibition at $120 \mathrm{pm} \alpha \mathrm{Bgt}$ and a maximal inhibition of $47 \%$.

agonist was used to minimize loss of response because of receptor desensitization. Figure $1 A$ shows a representative membrane current response evoked by $500 \mu \mathrm{M}$ ACh from a neuron electrically accessed with the amphoterecin B perforated-patch method and voltage clamped at $-60 \mathrm{mV}$. ACh elicited a transient inward current that desensitized during the $2 \mathrm{sec}$ exposure to agonist. After a $10 \mathrm{~min}$ application of $100 \mathrm{~nm} \alpha \mathrm{Bgt}$, the ACh-evoked current decreased by $>40 \%$ in amplitude (Fig. $1 A$ ). Mean values of $2.3 \pm 0.3$ and $1.3 \pm 0.3 \mathrm{nA}(n=5$ cells $)$ were obtained for the peak response in the absence and presence, respectively, of 100 nM $\alpha$ Bgt. The $\alpha$ Bgt-induced decrement was statistically significant $(p<0.02)$. Similar values for the peak ACh-induced currents plus and minus $\alpha \mathrm{Bgt}$ were observed when cells were electrically accessed using the conventional patch-clamp (dialyzing) whole-cell recording configuration: $1.6 \pm 0.2$ and $2.5 \pm 0.2 \mathrm{nA}$, respectively ( $n=4$ cells).

For comparison, ACh-induced currents were also recorded from dissociated chick ciliary ganglion neurons before and after 
A

B
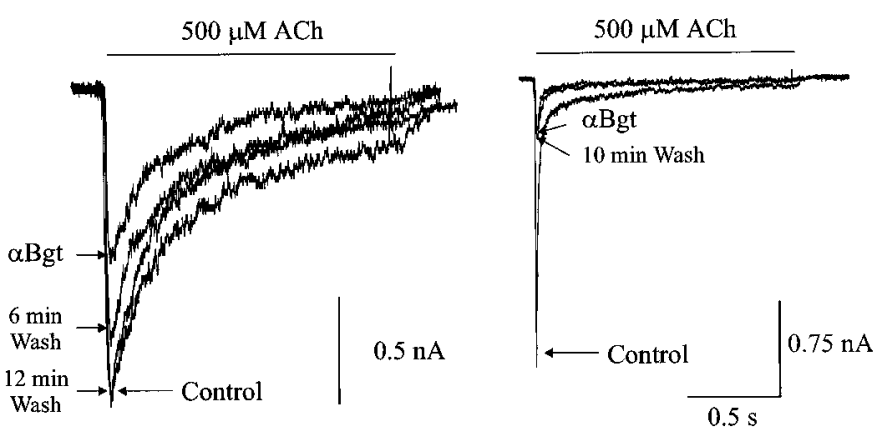

$\mathrm{C}$

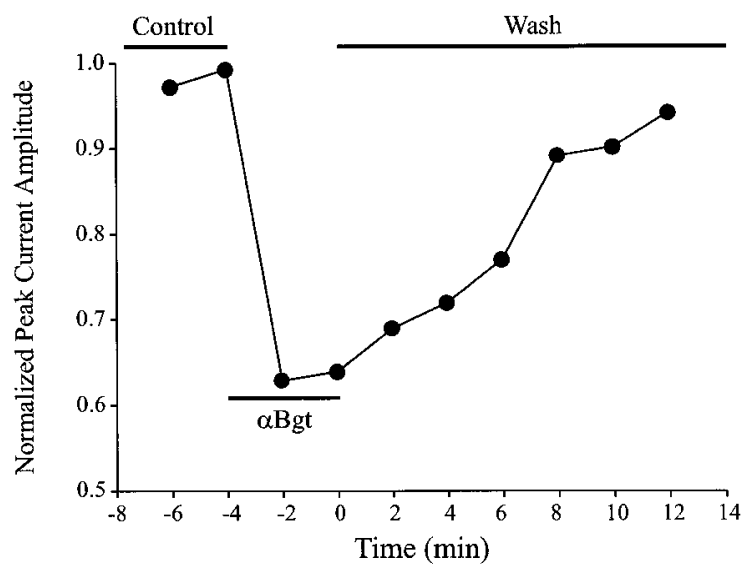

Figure 3. Reversibility of $\alpha$ Bgt-induced blockade. $A, B$, A family of currents evoked by $500 \mu \mathrm{M}$ ACh recorded from a single rat intracardiac ganglion neuron $(A)$ and a single embryonic day 14 chick ciliary ganglion neuron $(B)$ at $-60 \mathrm{mV}$ in the absence (Control) and presence of $100 \mathrm{nM}$ $\alpha$ Bgt and after washout of toxin for the indicated time periods. $C$, ACh-evoked whole-cell current amplitudes before application (Control), during application $(\alpha B g t)$, and after removal (Wash) of $100 \mathrm{~nm} \alpha$ Bgt. Values have been normalized to the maximal response from the same cell and plotted as a function of time.

application of $100 \mathrm{~nm} \alpha \mathrm{Bgt}$ (Fig. $1 B$ ). As with intracardiac neurons, the cells were electrically accessed with the perforatedpatch method and were voltage clamped at $-60 \mathrm{mV}$. The time course of the $\alpha$ Bgt-sensitive current in both cell types was determined by subtracting the ACh-evoked current recorded in the presence of $\alpha \mathrm{Bgt}$ from that recorded in its absence in the same cell (Fig. 1C). The $\alpha$ Bgt-sensitive response in rat intracardiac neurons decays much more slowly than does the response in ciliary ganglion neurons. The decay phase of the $\alpha$ Bgt-sensitive response in intracardiac neurons was best fit by the sum of two exponential functions with decay half-times of $170 \pm 20$ and $930 \pm 70 \mathrm{msec}(n=4$ cells $)$.

\section{Concentration dependence and reversibility of $\alpha$ Bgt blockade}

The concentration dependence of the $\alpha$ Bgt blockade was examined by comparing the peak amplitude of the ACh-induced current before and after application of $\alpha \mathrm{Bgt}$ at a range of concentrations ( $10 \mathrm{pm}$ to $1 \mu \mathrm{M}$ ). Figure $2 A$ shows a set of currents evoked in this manner from a single neuron voltage clamped at $-60 \mathrm{mV}$. Approximately $80 \%$ of the neurons (32 out of 41 cells) revealed an $\alpha$ Bgt-sensitive ACh response. The peak amplitude of ACh-
$\mathbf{A}$

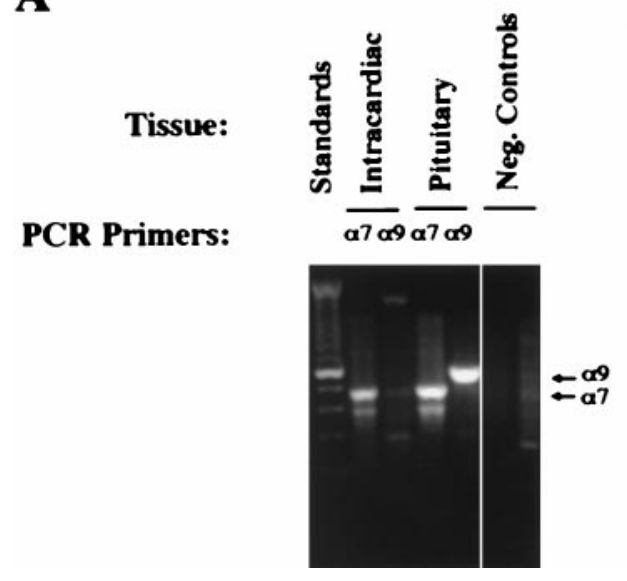

B

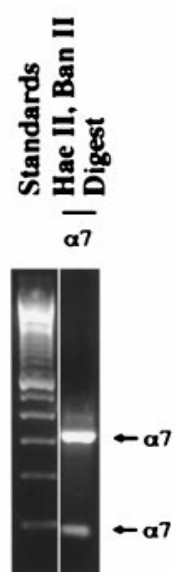

Figure 4. RT-PCR analysis of $\alpha 7$ and $\alpha 9$ gene expression in rat intracardiac ganglion neurons. $A$, RT-PCR products. Primers/template RNA: lane 1 (on the left), $100 \mathrm{bp}$ standards; lane 2, $\alpha 7$ /intracardiac ganglion; lane 3, $\alpha 9$ /intracardiac ganglion; lane 4, $\alpha 7 /$ rat pituitary; lane 5, $\alpha 9$ /rat pituitary; lane 6, $\alpha 7+\alpha 9$ /water; lane 7, $\alpha 7+\alpha 9 /$ rat intracardiac without RT. The expected product sizes are 476 bp for $\alpha 7$ and 573 bp for $\alpha 9$. B, Restriction digest of the RT-PCR product amplified from intracardiac ganglion RNA with $\alpha 7$ primers. Lane 1 (on the left), 100 bp standards; lane 2, HaeII and BanII digest. Expected product sizes are 321, 78, and $77 \mathrm{bp}$ for $\alpha 7$ transcripts. Neg., Negative.

evoked currents in the presence of $\alpha \mathrm{Bgt}$ was normalized to the maximum response from the same neuron in the absence of $\alpha \mathrm{Bgt}$, and the results from a number of cells were compiled to generate a plot of mean peak amplitude versus $\alpha$ Bgt concentration (Fig. $2 B)$. A fit of the data using a single-site adsorption isotherm indicates half-maximal inhibition $\left(\mathrm{IC}_{50}\right)$ at $120 \mathrm{pm}$ and a maximal inhibition of $47 \pm 2 \%$ at $1 \mu \mathrm{M} \alpha \mathrm{Bgt}(n=7)$.

The duration of $\alpha$ Bgt blockade was determined by comparing the peak amplitude of ACh-evoked currents in the same neuron before, during, and after exposure to $100 \mathrm{~nm} \alpha$ Bgt. Results from individual intracardiac ganglion neurons suggest the response largely recovers after only a few minutes of rinsing to remove toxin (Fig. $3 A$ ). For comparison, similar experiments were performed on chick ciliary ganglion neurons, which have been reported previously to show no reversibility of the $\alpha$ Bgt blockade over short times (Zhang et al., 1994). A 10 min wash under the same conditions used for the intracardiac neurons allows no recovery of the $\alpha$ Bgt-sensitive component in ciliary ganglion neurons (Fig. 3B) The peak amplitudes of the ACh-evoked currents obtained from individual intracardiac ganglion neurons throughout the procedure were normalized to the maximum response obtained from the same neuron before application of $\alpha$ Bgt application. Compiling such results from a number of neurons indicates that the onset of blockade in $100 \mathrm{~nm} \alpha$ Bgt occurs within 2 min but quickly reverses (Fig. 3C). After $10 \mathrm{~min}$ of rinsing to remove the toxin, the ACh-evoked currents had recovered to $87 \pm 5 \%$ of control values $(n=6)$.

\section{AChR gene transcripts: $\alpha \mathbf{7}$ versus $\alpha \mathbf{9}$}

The quick reversibility of the $\alpha \mathrm{Bgt}$ blockade and the slow desensitization of the $\alpha$ Bgt-sensitive response in rat intracardiac ganglion were unexpected. Although many of the neurons express the $\alpha 7$ gene (Poth et al., 1997), $\alpha 7$-AChRs in other systems generate rapidly desensitizing currents that are essentially irreversibly blocked by $\alpha$ Bgt (Zorumski et al., 1992; Alkondon and Albuquerque, 1993; Zhang et al., 1994; Blumenthal et al., 1997). The only 
A
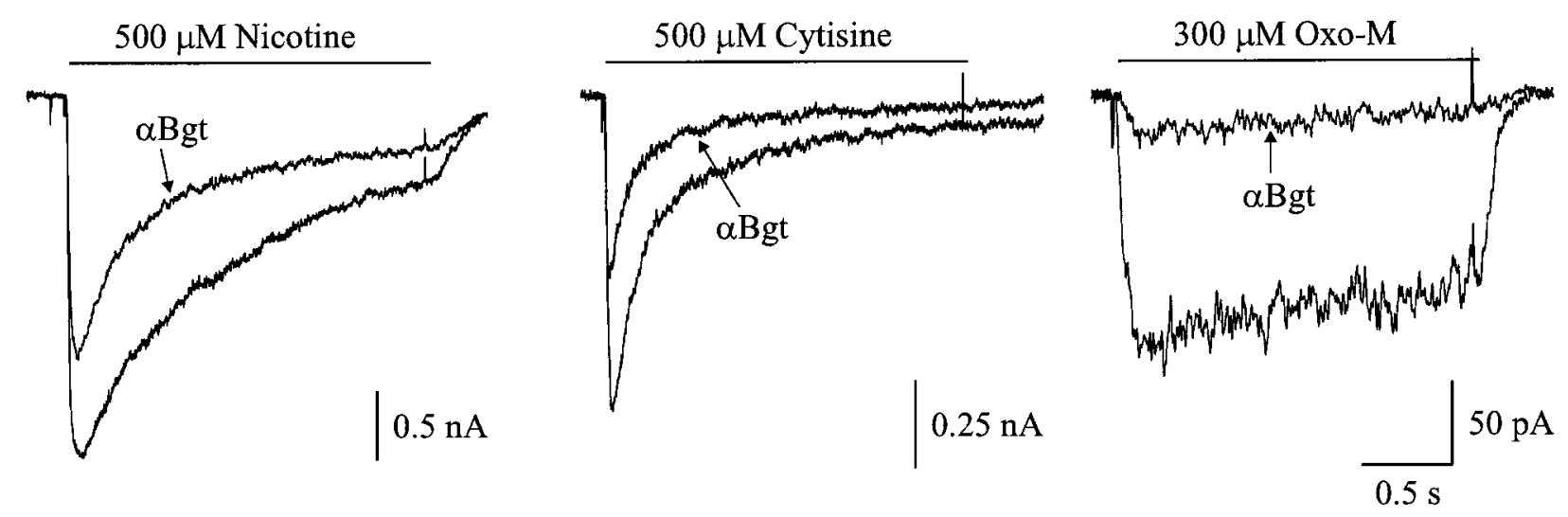

B
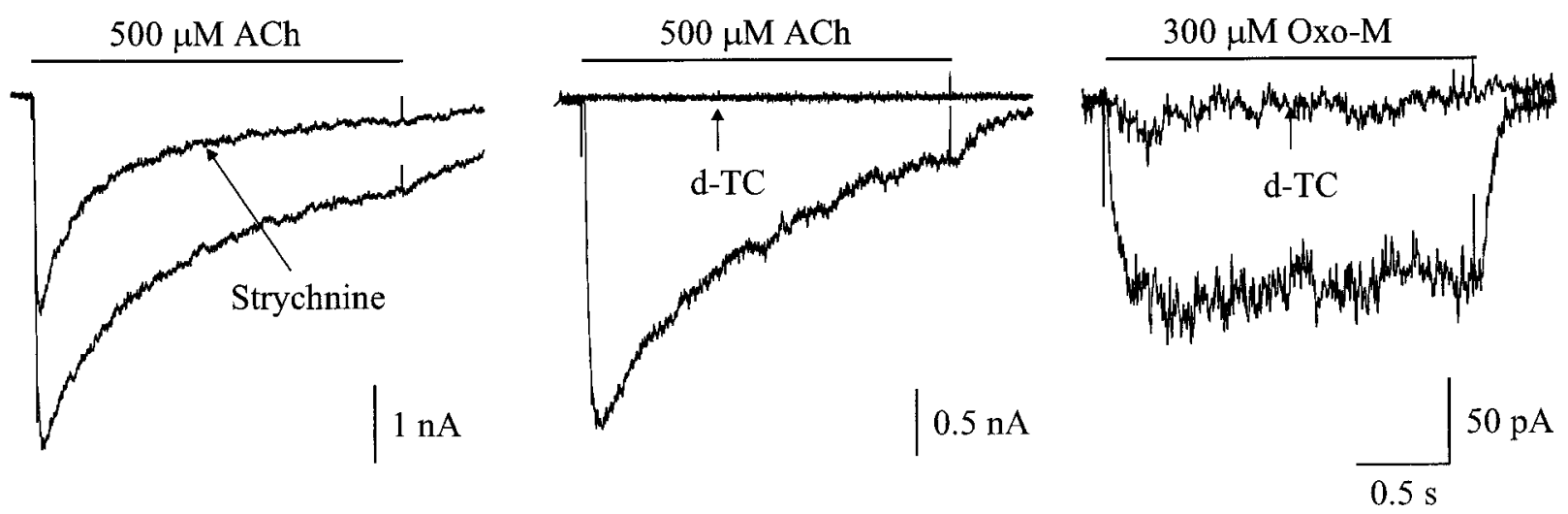

Figure 5. Pharmacology of $\alpha$ Bgt-sensitive currents in intracardiac ganglion neurons. $A$, Currents evoked by rapid focal application of $500 \mu \mathrm{M}$ nicotine (left), $500 \mu \mathrm{M}$ cytisine (middle), and $300 \mu \mathrm{M}$ Oxo-M (right) in the absence and presence of $\alpha$ Bgt. B, ACh-evoked (left and middle) and Oxo-M-evoked (right) responses before and after treatment with $100 \mathrm{nM}$ strychnine or $100 \mu \mathrm{M}$ D-tubocurarine $(D-T C)$.

candidates for AChRs in rat that produce slowly desensitizing currents that are reversibly blocked by $\alpha \mathrm{Bgt}$ are those composed of the $\alpha 9$ gene product (Elgoyhen et al., 1994). The $\alpha 9$ gene appears to be expressed exclusively in non-neuronal cells (Elgoyhen et al., 1994), but it seemed prudent to test whether $\alpha 9$ transcripts could be detected in intracardiac ganglia. This was done using RT-PCR.

Total RNA was extracted from cultures of rat intracardiac neurons, reverse-transcribed, and amplified by PCR for $\alpha 7$ and $\alpha 9$ transcripts (Fig. $4 A$ ). The primers were designed to span introns so that false positives resulting from genomic DNA contamination could be distinguished. Reactions with $\alpha 7$ primers generated a band having the expected size for the $\alpha 7$ product (476 bp) from intracardiac ganglion RNA. No band of the size expected for the $\alpha 9$ product (573 bp) was generated from intracardiac ganglion RNA when $\alpha 9$ primers were used. Positive controls for the RTPCR were performed with RNA extracted from neonatal rat pituitary ganglia because both $\alpha 7$ and $\alpha 9$ mRNAs are known to be present in this case (Elgoyhen et al., 1994). Both $\alpha 7$ and $\alpha 9$ products were generated using the appropriate primers (Fig. $4 A$ ). Two sets of negative controls were conducted; these include omission of reverse transcriptase from the RT incubation and substitution of water for template in the PCR incubation (Fig. $4 A$ ). Restriction digestion (Lambolez et al., 1992) provided ad- ditional evidence that the major PCR product obtained with the $\alpha 7$ primers ( $\sim 476 \mathrm{bp}$ ) originated from the $\alpha 7$ transcript (Fig. $4 B$ ). The digestion yielded products of the predicted sizes $(321,77$, and $78 \mathrm{bp}$ ). Sequence analysis confirmed that the major PCR product had the expected $\alpha 7$ sequence; the smaller product of $\sim 390 \mathrm{bp}$ (Fig. $4 A$ ) was not $\alpha 7$ in origin (data not shown).

\section{Pharmacology of $\alpha$ Bgt-sensitive currents}

The pharmacology of $\alpha \mathrm{Bgt}$-sensitive ACh responses in dissociated intracardiac ganglion neurons was examined to determine whether the currents had the properties expected for $\alpha 7$-AChRs. Although ACh activates both $\alpha 7$ - and $\alpha 9$-AChRs, cytisine and nicotine activate only the former. Cytisine fails to activate $\alpha 9$ AChRs, whereas nicotine blocks such receptors (Elgoyhen et al., 1994). The M1 muscarinic agonist oxotremorine M (Oxo-M) activates both classes of receptors, whereas the glycinergic antagonist strychnine and the nicotinic antagonist D-tubocurarine block both.

Figure $5 A$ shows representative membrane currents evoked by focal application of $500 \mu \mathrm{M}$ nicotine, $500 \mu \mathrm{M}$ cytisine, and $300 \mu \mathrm{M}$ Oxo-M in the presence and absence of $100 \mathrm{~nm} \alpha$ Bgt. With nicotine and cytisine as agonists, $\alpha$ Bgt blocked $37 \pm 3 \%(n=3)$ and $41 \pm 3(n=3)$ of the current, respectively. These values are similar to those obtained with $\mathrm{ACh}$ as agonist and are consistent 
A

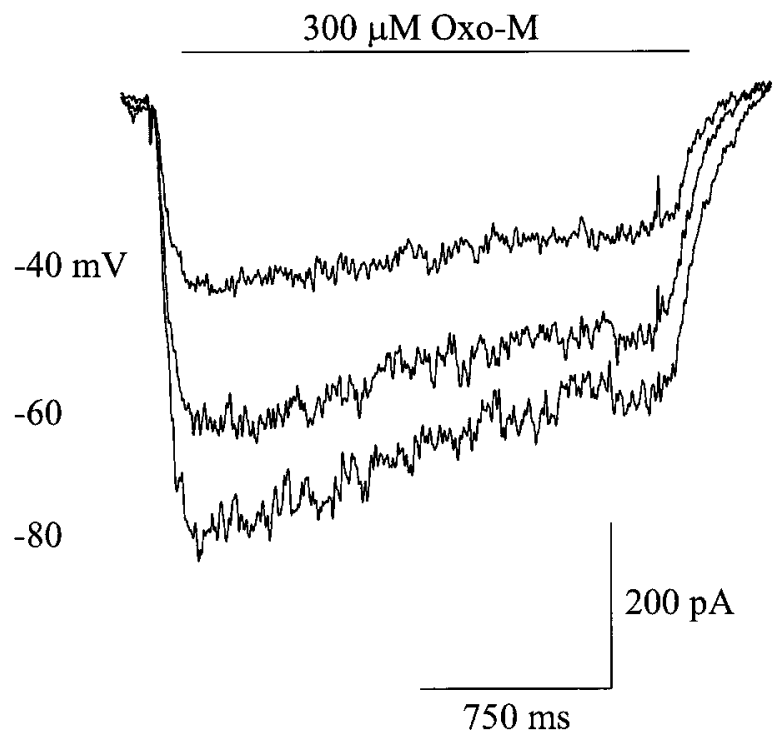

B

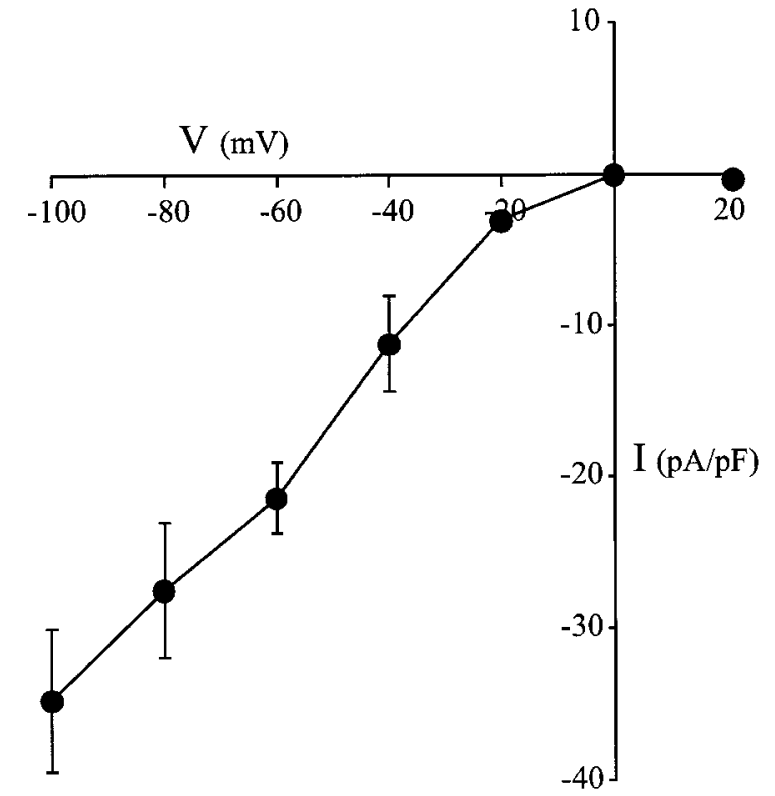

Figure 6. Voltage dependence of peak Oxo-M-evoked current amplitude. $A$, A family of currents evoked by $300 \mu \mathrm{M}$ Oxo-M in the presence of $100 \mathrm{nM}$ atropine, recorded from a neuron held at the indicated membrane potentials. $B$, Current-voltage relationship for currents induced by $300 \mu \mathrm{M}$ Oxo-M. Points represent mean \pm SEM for three neurons each.

with the $\alpha$ Bgt-sensitive response being the product of $\alpha 7$-AChRs. With Oxo-M as agonist, $\alpha$ Bgt blocked $87 \pm 5 \%(n=2)$ of the current. Strychnine blocked $43 \pm 6 \%(n=3)$ of the ACh-evoked current, a value comparable with the fractional response blocked by $\alpha$ Bgt (Fig. $5 B$ ). The broad spectrum nicotinic antagonist D-tubocurarine at $100 \mu \mathrm{M}$ blocked the ACh-evoked responses as well as those induced by Oxo-M (Fig. 5B). The current-voltage relationship of the $\alpha \mathrm{Bgt}$-sensitive currents induced by Oxo-M is that expected for cation-selective neuronal AChRs, namely, a linear relationship at negative potentials, a reversal potential near $0 \mathrm{mV}$, and marked inward rectification visible at positive membrane potentials (Fig. 6). The results support the conclusion that the slowly desensitizing, $\alpha$ Bgt-sensitive currents obtained from intracardiac ganglion neurons are produced by activation of $\alpha 7-A C h R s$.

\section{Quantification of $\alpha 7-A C h R s$ in rat intracardiac ganglion extracts}

The number of $\alpha 7$-AChRs present in intracardiac ganglia was measured with a solid-phase immunoprecipitation assay. Extracts were prepared from P4 rat intracardiac ganglia and incubated with the anti- $\alpha 7 \mathrm{mAb} 319$ to immunotether $\alpha 7$-AChRs. Bound receptors were quantified with ${ }^{125} \mathrm{I}-\alpha \mathrm{Bgt}$. A single round yielded nearly 5 fmol of binding sites per heart equivalent of intracardiac ganglia (Fig. 7A). A second round yielded an additional $0.5 \mathrm{fmol}$, indicating that most of the $\alpha 7$-AChRs had been collected in the first pass. The recovered extracts were then incubated with $\left[{ }^{3} \mathrm{H}\right]$ epibatidine and filtered to collect and quantify other classes of neuronal AChRs (Gerzanich et al., 1995; Houghtling et al., 1995; Conroy and Berg, 1998). This procedure yielded $\sim 2-3 \mathrm{fmol}$ per $\mathrm{P} 4$ heart equivalent of intracardiac ganglia (Fig. $7 A$ ). No toxin binding was detected in the solid-phase assay when either the anti- $\alpha 8 \mathrm{mAb} 308$ or the anti- $\beta 2 \mathrm{mAb} 270$ was used to immunotether AChRs, nor was any $\left[{ }^{3} \mathrm{H}\right]$ epibatidine binding detected in the assay when the anti- $\alpha 7 \mathrm{mAb} 319$ was used to immunotether AChRs (data not shown).

The numbers of $\alpha 7$-AChRs per heart equivalent of ganglia did not change dramatically during early postnatal development. Values obtained with P14 ganglia were not significantly greater than those obtained at P4 (Fig. $7 B$ ). The binding was specific for the ganglia because a large excess of tissue that might have contaminated ganglia preparations (namely, small segments of atria, ventricles, thymus gland, aorta, and lungs) failed to display significant binding on their own (Fig. 7B).

\section{Selective blockade of $\alpha$ Bgt-sensitive currents by anti- $\alpha 7$ mAbs}

To obtain further evidence that the $\alpha \mathrm{Bgt}$-sensitive currents in intracardiac ganglion neurons are mediated by activation of $\alpha 7$ AChRs, we dialyzed cells intracellularly with subunit-specific mAbs. The hope was that mAbs specific for intracellular epitopes on particular AChR subunits might bind to those sites on native receptors in situ and inhibit receptor function either by occluding the channel from the inside or by preventing allosteric or regulatory changes required for channel opening.

Intracellular dialysis of neurons via a conventional patch pipette for periods up to $30 \mathrm{~min}$ with $\mathrm{mAb} 35$, which recognizes extracellular epitopes on the $\alpha 1, \alpha 3$, and $\alpha 5$ but not $\alpha 7$ subunits, had no statistically significant effect either on the total AChevoked current or on that portion that could be blocked by $\alpha \mathrm{Bgt}$ (Fig. 8). Similarly, intracellular dialysis with mAb 313, which is specific for an intracellular epitope on $\alpha 3$ subunits, had no effect on either component of the response. In contrast, intracellular dialysis for even 10 min with mAb 319, which is specific for an intracellular epitope on $\alpha 7$ subunits, produced a significant and specific decrement in the $\alpha$ Bgt-sensitive portion of the AChevoked response (Fig. 8). Dialysis with mAb 319 for periods up to $30 \mathrm{~min}$ produced an even greater selective reduction in the 
A

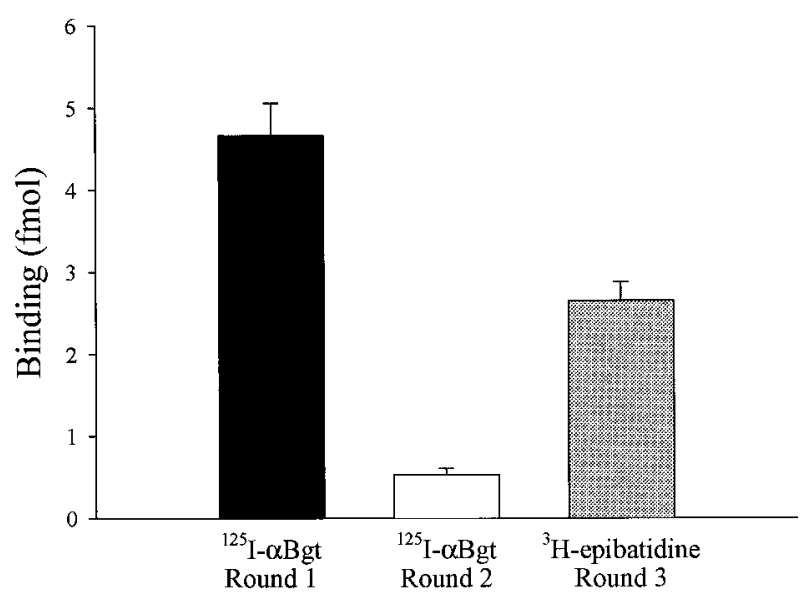

B

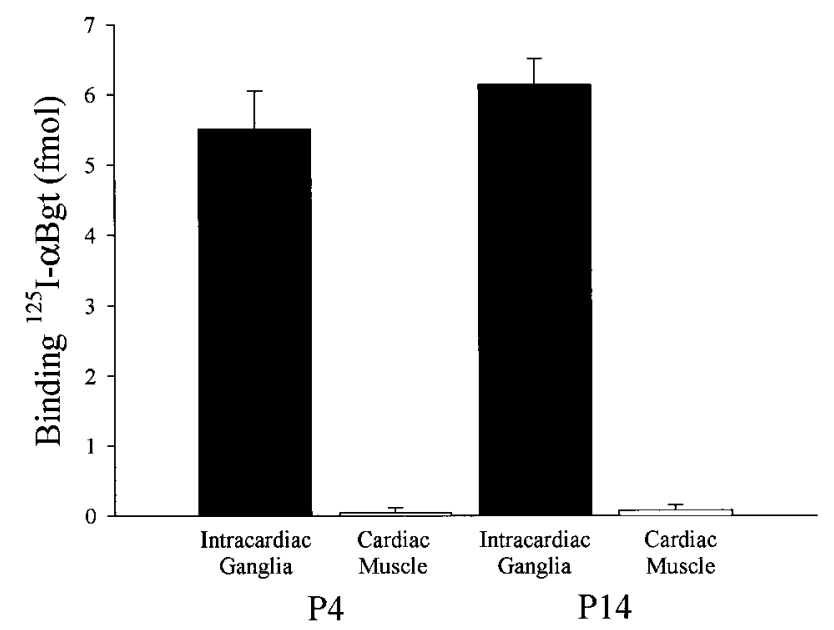

Figure 7. Quantification of $\alpha 7$-AChRs using a solid-phase immunoprecipitation assay. $A$, Solubilized intracardiac ganglion $\alpha 7$-AChRs were immunotethered with the anti- $\alpha 7 \mathrm{mAb} 319$ in two sequential rounds (Rounds 1 and 2) and then quantified with ${ }^{125} \mathrm{I}-\alpha \mathrm{Bgt}$; the recovered supernatant fractions were then assayed for $\left[{ }^{3} \mathrm{H}\right]$ epibatidine-binding receptors using a polyethyleneimine filter assay (Round 3). Bars represent the mean ( \pm SEM) amount of binding per single heart equivalent of intracardiac ganglia for 11 (black bar), 8 (white bar), or 3 (shaded bar) determinations. $B,{ }^{125} \mathrm{I}-\alpha \mathrm{Bgt}$ binding sites in solubilized tissue samples (Rounds 1 and 2 summed) are shown. Bars represent the mean ( \pm SEM) amount of binding per single heart equivalent of intracardiac ganglia (black bars) or an $\sim 10$-fold excess by weight of cardiac muscle tissue (white bars), a small portion of which might have contaminated the ganglia samples. Eight determinations were done for P4 samples, and three determinations were performed for P14 samples.

toxin-blockable response. Thus only $11 \pm 2 \%$ (mean \pm SEM) of the whole-cell $\mathrm{ACh}$ response was $\alpha \mathrm{Bgt}$-sensitive at $30 \mathrm{~min}$, whereas $22 \pm 3 \%$ was $\alpha$ Bgt-sensitive at $10 \min (p=0.01$ for 10 vs 30 min values). Both components comprising the decay phase of the $\alpha$ Bgt-sensitive response were affected. No preferential rundown of the $\alpha$ Bgt-sensitive response occurred under these conditions, as can be seen by comparing the 10 and 30 min values for cells receiving the control mAbs 35 and 313 (Fig. 8). The results provide strong evidence for the conclusion that $\alpha 7-\mathrm{AChRs}$ are responsible for the slowly desensitizing ACh-evoked responses that are reversibly blocked by $\alpha$ Bgt.

\section{DISCUSSION}

The results presented here provide the first demonstration of ACh-evoked currents in the mammalian peripheral nervous system attributable to $\alpha 7-\mathrm{AChRs}$. The currents are blocked by nanomolar concentrations of $\alpha \mathrm{Bgt}$, but, unexpectedly, the blockade is rapidly reversible and the currents affected are slow to desensitize. In all previous cases in which native $\alpha 7$-AChRs have been activated by rapid application of agonist, the resulting currents were found to desensitize rapidly and to remain inhibited long after unbound $\alpha \mathrm{Bgt}$ had been removed. In addition to chick ciliary ganglion neurons (Zhang et al., 1994), examples include rat hippocampal neurons in culture (Zorumski et al., 1992; Alkondon and Albuquerque, 1993) and the rat pheochromocytoma cell line PC12 (Blumenthal et al., 1997). Clearly some populations of rat $\alpha 7$-AChRs are capable of rapid desensitization and long-lasting $\alpha \mathrm{Bgt}$ blockade. The rapidly reversible blockade described here may explain why no $\alpha$ Bgt-sensitive currents have been reported previously for mammalian autonomic neurons.

The $\alpha 9$ gene is known to produce AChRs that slowly desensitize and reversibly bind $\alpha \mathrm{Bgt}$, but all evidence to date indicates the gene is not expressed in neurons (Elgoyhen et al., 1994). RT-PCR analysis in the present experiments failed to detect $\alpha 9$ transcripts in rat intracardiac ganglion RNA, although the positive controls with rat pituitary RNA proved successful. Moreover, the pharmacology of the $\alpha$ Bgt-sensitive response in intracardiac ganglion neurons was consistent with that of $\alpha 7$-AChRs rather than that of $\alpha 9-\mathrm{AChRs}$, and immunoprecipitation experiments confirmed the presence of $\alpha 7$-AChRs in intracardiac ganglion extracts.

The number of $\alpha 7$-AChRs detected by ${ }^{125} \mathrm{I}-\alpha \mathrm{Bgt}$ binding in $\mathrm{P} 4$ rat intracardiac ganglia ( $\sim 5 \mathrm{fmol}$ per heart equivalent) was substantially lower than the $\sim 30$ fmol per ganglion observed for P4 rat superior cervical ganglia in the same assay (A. Roth and $\mathrm{J}$. Cuevas, unpublished results) or the $\sim 20 \mathrm{fmol}$ per ganglion for chick ciliary ganglia at a comparable stage of development (Chiappinelli and Giacobini, 1978; Smith et al., 1983). Intracardiac ganglia, however, contain only $\sim 4 \times 10^{3}$ neurons in aggregate per heart equivalent, whereas rat superior cervical ganglia contain $\sim 3 \times 10^{4}$ (Paxinos, 1995), and chick ciliary ganglia contain $\sim 3 \times 10^{3}$ (Landmesser and Pilar, 1974). When the amount of ${ }^{125} \mathrm{I}-\alpha \mathrm{Bgt}$ binding is normalized for the number of neurons estimated to be present, the number of sites is comparable for the two mammalian sources $\left(\sim 1\right.$ fmol per $10^{3}$ neurons) but is lower than that found in chick ciliary ganglia $(\sim 7 \mathrm{fmol}$ per $10^{3}$ neurons).

One of the strongest lines of evidence indicating that the $\alpha$ Bgt-sensitive responses arise from $\alpha 7$-AChRs was provided by the intracellular dialysis experiments with subunit-specific mAbs. The fact that anti- $\alpha 7 \mathrm{mAbs}$ selectively reduced the $\alpha$ Bgt-sensitive ACh-evoked current while other mAbs had no effect on either the $\alpha$ Bgt-sensitive or -resistant components of the response clearly implicates $\alpha 7$-AChRs in producing the toxin-sensitive portion of the response. One might have expected the anti- $\alpha 3 \mathrm{mAb} 313$ to reduce the $\alpha$ Bgt-resistant response because it almost certainly arises from $\alpha 3$-containing AChRs (Poth et al., 1997). It is not known, however, whether mAb 313 recognizes rat $\alpha 3$ protein as it does chick $\alpha 3$; many subunit-specific anti-AChR mAbs do not cross-react between chick and rat proteins (W. Conroy and D. Berg, unpublished results). Some, but not all, anti-AChR mAbs previously tested on receptors reconstituted in artificial membranes were able to influence single channel properties (Blatt et 
A
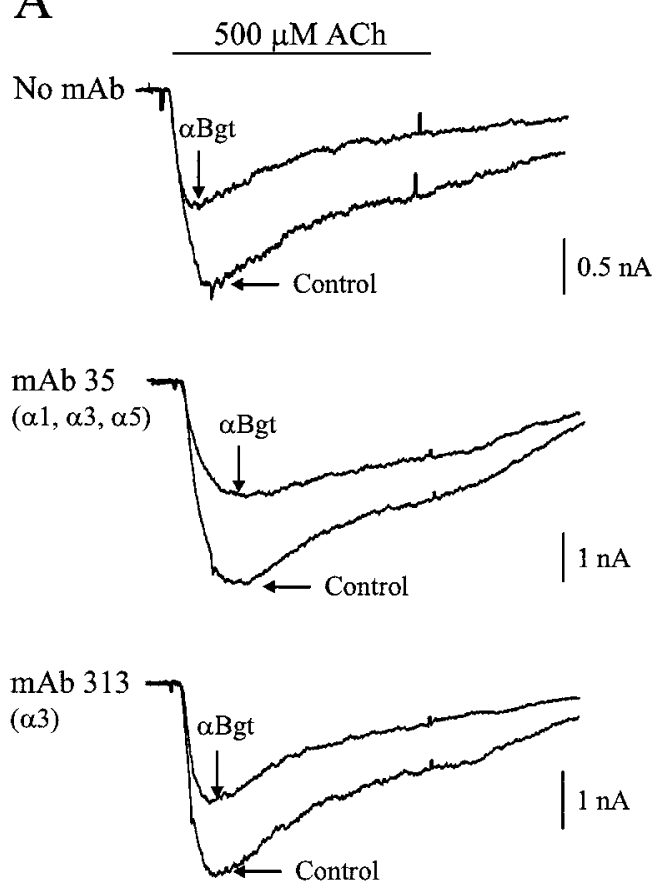

$\mathrm{mAb} 319$

$(\alpha 7)$

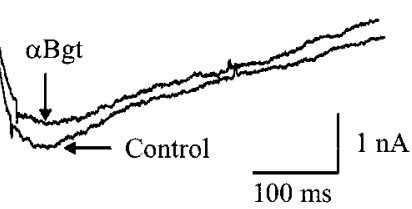

B

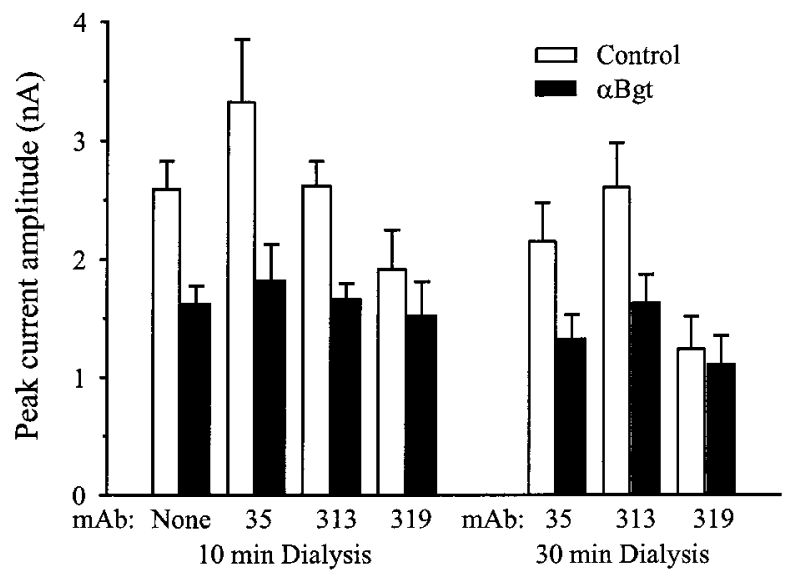

$\mathrm{C}$

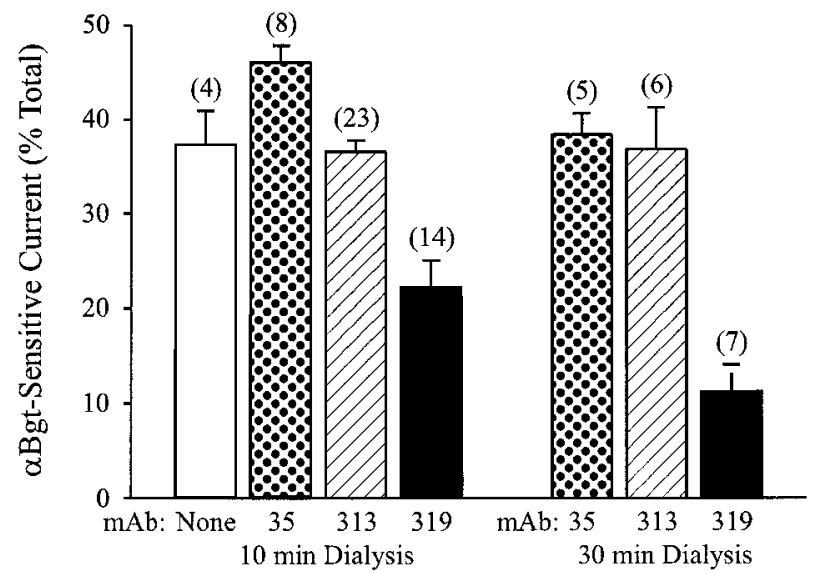

Figure 8. Specific blockade of $\alpha$ Bgt-sensitive ACh-evoked currents by intracellular dialysis with an anti- $\alpha 7 \mathrm{mAb}$. $A$, Whole-cell currents evoked by focal application of $500 \mu \mathrm{M}$ ACh onto an intracardiac ganglion neuron in the absence (Control) and presence of $50 \mathrm{nM} \alpha \mathrm{Bgt}$ after a $10 \mathrm{~min}$ intracellular dialysis of the cell with either no $\mathrm{mAb}$, the anti- $\alpha 1 / \alpha 3 / \alpha 5 \mathrm{mAb} 35$, the anti- $\alpha 3 \mathrm{mAb} 313$, or the anti- $\alpha 7 \mathrm{mAb} 319$ via the patch pipette. $B$, Peak currents evoked by $500 \mu \mathrm{M}$ ACh (white bars) and ACh plus $50 \mathrm{~nm} \alpha \mathrm{Bgt}$ (black bars) from neurons dialyzed with the indicated mAbs. Currents were recorded after a 10 and a 30 min dialysis. $C$, The $\alpha$ Bgt-sensitive portion of the ACh-evoked current expressed as a percent of the peak whole-cell ACh response current for neurons after dialysis for either 10 or $30 \mathrm{~min}$ with the indicated mAbs. Only the anti- $\alpha 7 \mathrm{mAb}$ affected the whole cell response, and it selectively reduced the $\alpha$ Bgt-sensitive portion of it. Bars represent the mean \pm SEM of the number of neurons indicated in parentheses; the same number of neurons was tested in $B$ and $C$.

al., 1986). If intracellular dialysis with appropriate subunitspecific mAbs proves to be widely applicable for selectively targeting receptor subtypes in situ, it may prove powerful for correlating individual receptor species with unique functional responses.

The intracellular mechanism by which the mAbs block receptor function is of considerable interest. Possibly the antibodies simply occlude the ion channel from the cytoplasmic side. Alternatively, the antibodies may prevent a conformational change required for channel opening. Extensive evidence suggests muscle AChRs undergo such conformational changes (Karlin and Akabas, 1996), and a recent report indicates that the large cytoplasmic loop influences channel function (Milone et al., 1998). Another possibility is that the mAbs may prevent an intermolecular interaction such as receptor phosphorylation or linkage to a cytoskeletal element required to optimize receptor functionality. Future experiments will explore these possibilities.

The finding that rat intracardiac ganglion $\alpha 7$-AChRs behave quite differently from rat hippocampal and PC12 $\alpha 7$-AChRs invites speculation. It is possible that the rat $\alpha 7$ gene product can combine with other as yet unidentified subunits to produce het- eromeric receptors with different properties. The rat $\alpha 7$ gene product can coassemble with muscle AChR subunits under some conditions when coexpressed in Xenopus oocytes (Helekar et al., 1994), but it has not been shown to do so with any of the known AChR gene products in vivo. No new rat AChR gene products have been identified since $\alpha 9$, and $\alpha 9$ is non-neuronal with a very limited pattern of expression. Nonetheless, if an AChR gene were primarily confined to expression in subpopulations of autonomic neurons, it could well have escaped detection. Similar considerations apply to hypotheses based on $\alpha 7$ splice variants generating receptors with different properties.

A different kind of explanation is that the functional differences among rat $\alpha 7$-AChR populations may be produced by cell-specific or location-specific regulatory interactions. The diverse functions currently attributed to $\alpha 7$-AChRs (McGehee et al., 1995; Gray et al., 1996; Zhang et al., 1996; Coggan et al., 1997; Fu and Liu, 1997; Ullian et al., 1997) could certainly necessitate complex regulatory options. Perhaps the most likely mechanism is one using some form of second messenger-mediated receptor phosphorylation (Huganir and Greengard, 1990). Alternatively, receptor interactions with the cytoskeleton and associated mole- 
cules could alter receptor function, as suggested above. Intracellular dialysis of neurons via the patch pipette should provide a means for manipulating the cytoplasmic milieu and testing several of these hypotheses.

A final issue is the significance of $\alpha 7$-AChRs for signaling through intracardiac ganglia. Approximately one-half of the intracardiac ganglion neurons sampled by single-cell RT-PCR were shown to have an $\alpha 7$ transcript (Poth et al., 1997), and, in approximate agreement, $\sim 80 \%$ of the neurons tested here displayed $\alpha$ Bgt-sensitive $\mathrm{ACh}$ responses. It is not known which neuronal subpopulations in the ganglia such cells comprise, but they are likely to include the large principal neurons that innervate cardiac muscle directly.

If intracardiac ganglion $\alpha 7-\mathrm{AChRs}$ retain the high relative calcium permeability observed for $\alpha 7$-AChRs elsewhere (Bertrand et al., 1993; Seguela et al., 1993), their resistance to desensitization could enable them to have a major impact on calcium-dependent events in the neurons. Changes in intracellular calcium, for example, modulate the firing patterns of intracardiac ganglion neurons (Allen and Burnstock, 1987). Such changes in neuronal firing properties may be a mechanism by which integration of neuronal signals and coding of information occur in mammalian intracardiac ganglia (Cuevas et al., 1997). A portion of the receptors may be destined for presynaptic sites on the cells. In this case a slow rate of desensitization coupled with a high relative calcium permeability could have a major effect on modulation of transmitter release by the receptors, a role advanced previously for them in other systems (McGehee et al., 1995; Gray et al., 1996; Coggan et al., 1997). Either of these effects could enable $\alpha 7$-AChRs to be a major contributor to the neural circuit that exerts local control over cardiac function.

\section{REFERENCES}

Alkondon M, Albuquerque EX (1993) Diversity of nicotinic acetylcholine receptors in rat hippocampal neurons. I. Pharmacological and functional evidence for distinct structural subtypes. J Pharmacol Exp Ther 265:1455-1473.

Allen TGJ, Burnstock G (1987) Intracellular studies of the electrophysiological properties of cultured intracardiac neurones of the guinea-pig. J Physiol (Lond) 388:349-366.

Anand R, Peng X, Ballesta J, Lindstrom J (1993a) Pharmacological characterization of $\alpha$-bungarotoxin-sensitive acetylcholine receptors immunoisolated from chick retina: contrasting properties of $\alpha 7$ and $\alpha 8$ subunit-containing subtypes. Mol Pharmacol 44:1046-1050.

Anand R, Peng X, Lindstrom J (1993b) Homomeric and native $\alpha 7$ acetylcholine receptors exhibit remarkably similar but non-identical pharmacological properties, suggesting that the native receptor is a heteromeric protein complex. FEBS Lett 327:241-246.

Ascher P, Large WA, Rang HP (1979) Studies on the mechanism of action of acetylcholine antagonists on rat parasympathetic ganglion cells. J Physiol (Lond) 295:139-170.

Bertrand D, Galzi JL, Devillers-Thiéry A, Bertrand S, Changeux JP (1993) Mutations at two distinct sites within the channel domain M2 alter calcium permeability of neuronal $\alpha 7$ nicotinic receptor. Proc Natl Acad Sci USA 90:6971-6975.

Betz H (1981) Characterization of the $\alpha$-bungarotoxin receptor in chick embryo retina. Eur J Biochem 117:131-139.

Blatt Y, Montal MS, Lindstrom JM, Montal M (1986) Monoclonal antibodies specific to the $\beta$ and $\gamma$ subunits of the Torpedo acetylcholine receptor inhibit single-channel activity. J Neurosci 6:481-486.

Blumenthal EM, Conroy WG, Romano SJ, Kassner PD, Berg DK (1997) Detection of functional nicotinic receptors blocked by $\alpha$-bungarotoxin on PC12 cells and dependence of their expression on posttranslational events. J Neurosci 17:6094-6104.
Brown DA, Fumagalli L (1977) Dissociation of $\alpha$-bungarotoxin binding and receptor block in the rat superior cervical ganglion. Brain Res 129:165-168.

Carbonetto SR, Fambrough DM, Muller KJ (1978) Non-equivalence of $\alpha$-bungarotoxin receptors and acetylcholine receptors in chick sympathetic neurons. Proc Natl Acad Sci USA 75:1016-1020.

Chen D, Patrick JW (1997) The $\alpha$-bungarotoxin-binding nicotinic acetylcholine receptor from rat brain contains only the $\alpha 7$ subunit. J Biol Chem 272:24024-24029.

Chiappinelli VA, Giacobini E (1978) Time course of appearance of $\alpha$-bungarotoxin binding sites during development of chick ciliary ganglion and iris. Neurochem Res 3:465-478.

Coggan JS, Paysan J, Conroy WG, Berg DK (1997) Direct recording of nicotinic responses in presynaptic nerve terminals. J Neurosci 17:5798-5806.

Conroy WG, Berg DK (1995) Neurons can maintain multiple classes of nicotinic acetylcholine receptors distinguished by different subunit compositions. J Biol Chem 270:4424-4431.

Conroy WG, Berg DK (1998) Nicotinic receptor subtypes in the developing chick brain: appearance of a species containing the $\alpha 4, \beta 2$, and $\alpha 5$ gene products. Mol Pharmacol 53:392-401.

Conroy WG, Vernallis AB, Berg DK (1992) The $\alpha 5$ gene product assembles with multiple acetylcholine receptor subunits to form distinctive receptor subtypes in brain. Neuron 9:679-691.

Couturier S, Bertrand D, Matter J-M, Hernandez M-C, Bertrand S, Millar N, Valera S, Barkas T, Ballivet M (1990) A neuronal nicotinic acetylcholine receptor subunit $(\alpha 7)$ is developmentally regulated and forms a homo-oligomeric channel blocked by $\alpha$-Btx. Neuron 5:847-856.

Cuevas J, Adams DJ (1994) Local anaesthetic blockade of neuronal nicotinic $\mathrm{ACh}$ receptor channels in rat parasympathetic ganglion cells. Br J Pharmacol 111:663-672.

Cuevas J, Harper AA, Trequattrini C, Adams DJ (1997) Passive and active membrane properties of isolated rat intracardiac neurons: regulation by H- and M-currents. J Neurophysiol 78:1890-1902.

Duggan AW, Hall JG, Lee CY (1976) Alpha-bungarotoxin, cobra neurotoxin and excitation of Renshaw cells by acetylcholine. Brain Res 107:166-170.

Elgoyhen AB, Johnson DS, Boulter J, Vetter DE, Heinemann S (1994) $\alpha 9$ : an acetylcholine receptor with novel pharmacological properties expressed in rat cochlear hair cells. Cell 79:705-715.

Freedman R, Coon H, Myles-Worsley M, Orr-Urtreger A, Olincy A, Davis A, Polymeropoulos M, Holik J, Hopkins J, Hoff M, Rosenthal J, Waldo MC, Reimherr F, Wender P, Yaw J, Young DA, Breese CR, Adams C, Patterson D, Adler LE, Kruglyak L, Leonard S, Byerly W (1997) Linkage of a neurophysiological deficit in schizophrenia to chromosome 15 locus. Proc Natl Acad Sci USA 94:587-592.

Fu W-M, Liu J-J (1997) Regulation of acetylcholine release by presynaptic nicotinic receptors at developing neuromuscular synapses. Mol Pharmacol 51:390-398.

Gagliardi M, Randall WC, Bieger D, Wurster RD, Hopkins DA, Armour JA (1988) Activity of in vivo canine cardiac plexus neurons. Am J Physiol 255:H789-H800.

Gerzanich V, Anand R, Lindstrom J (1994) Homomers of $\alpha 8$ and $\alpha 7$ subunits of nicotinic receptors exhibit similar channel but contrasting binding site properties. Mol Pharmacol 45:212-220.

Gerzanich V, Peng X, Wang F, Wells G, Anand R, Fletcher S, Lindstrom J (1995) Comparative pharmacology of epibatidine: a potent agonist for neuronal nicotinic acetylcholine receptors. Mol Pharmacol 48:774-782.

Gray R, Rajan AS, Radcliffe KA, Yakehiro M, Dani JA (1996) Hippocampal synaptic transmission enhanced by low concentrations of nicotine. Nature 383:713-716.

Hamill OP, Marty A, Neher E, Sakmann B, Sigworth FJ (1981) Improved patch-clamp techniques for high-resolution current recordings from cells and cell-free membrane patches. Pflügers Arch 391:85-100.

Helekar SA, Char D, Neff S, Patrick J (1994) Prolyl isomerase requirement for the expression of functional homo-oligomeric ligand-gated ion channels. Neuron 12:179-189.

Horn R, Marty A (1988) Muscarinic activation of ionic currents measured by a new whole-cell recording method. J Gen Physiol 92:145-159.

Houghtling RA, Davila-Garcia MI, Kellar KJ (1995) Characterization of $( \pm)-\left[{ }^{3} \mathrm{H}\right]$ epibatidine binding to nicotinic cholinergic receptors in rat and human brain. Mol Pharmacol 48:280-287.

Huganir RL, Greengard P (1990) Regulation of neurotransmitter receptor desensitization by protein phosphorylation. Neuron 5:555-567. 
Karlin A, Akabas M (1996) Toward a structural basis for the function of the nicotinic acetylcholine receptors and their cousins. Neuron 15:1231-1244.

Lambolez B, Audinat A, Bochet P, Crepel F, Rossier J (1992) AMPA receptor subunits expressed by single Purkinje cells. Neuron 9:247-258.

Landmesser L, Pilar G (1974) Synaptic transmission and cell death during normal ganglionic development. J Physiol (Lond) 241:737-749.

Lipton SA, Aizenman E, Loring RH (1987) Neural nicotinic acetylcholine responses in solitary mammalian retinal ganglion cells. Pflügers Arch 410:37-43.

Mandelzys A, De Koninck P, Cooper E (1995) Agonist and toxin sensitivities of ACh-evoked currents on neurons expressing multiple nicotinic ACh receptor subunits. J Neurophysiol 74:1212-1221.

Margiotta JF, Gurantz D (1989) Changes in the number, function, and regulation of nicotinic acetylcholine receptors during neuronal development. Dev Biol 135:326-339.

Marks MJ, Stitzel JA, Romm E, Wehner JM, Collins AC (1986) Nicotinic binding sites in rat and mouse brain: comparison of acetylcholine, nicotine, and $\alpha$-bungarotoxin. Mol Pharmacol 30:427-436.

McGehee D, Heath M, Gelber S, Role LW (1995) Nicotine enhancement of fast excitatory synaptic transmission in CNS by presynaptic receptors. Science 269:1692-1697.

Milone M, Wang H-L, Ohno K, Prince R, Fukudome T, Shen X-M, Brengman JM, Griggs RC, Sine SM, Engel AG (1998) Mode switching kinetics produced by a naturally occurring mutation in the cytoplasmic loop of the human acetylcholine receptor $\epsilon$ subunit. Neuron 20:575-588.

Moravec J, Moravec M (1987) Intrinsic nerve plexus of mammalian heart: morphological basis of cardiac rhythmical activity? Intl Rev Cytol 106:89-147.

Nishi R, Berg DK (1981) Two components from eye tissue that differentially stimulate the growth and development of $\mathrm{CG}$ neurons in cell culture. J Neurosci 1:505-513.

Nurse CA, O'Lague PH (1975) Formation of cholinergic synapses between dissociated sympathetic neurons and skeletal myotubes of the rat in cell culture. Proc Natl Acad Sci USA 72:1955-1959.

Paxinos G (1995) The rat nervous system, 2nd Edition. San Diego: Academic.

Poth K, Nutter TJ, Cuevas J, Parker MJ, Adams DJ, Luetje CW (1997) Heterogeneity of nicotinic receptor class and subunit mRNA expression among individual parasympathetic neurones from rat intracardiac ganglia. J Neurosci 17:586-596.
Pugh PC, Berg DK (1994) Neuronal acetylcholine receptors that bind $\alpha$-bungarotoxin mediate neurite retraction in a calcium-dependent manner. J Neurosci 14:889-896.

Sargent PB, Garrett EN (1995) The characterization of $\alpha$-bungarotoxin receptors on the surface of parasympathetic neurons in the frog heart. Brain Res 680:99-107.

Schoepfer R, Conroy WG, Whiting P, Gore M, Lindstrom J (1990) Brain $\alpha$-bungarotoxin binding protein cDNAs and mAbs reveal subtypes of this branch of the ligand-gated ion channel gene superfamily. Neuron 5:35-48.

Seabrook GR, Fieber LA, Adams DJ (1990) Neurotransmission in neonatal rat cardiac ganglion in situ. Am J Physiol 259:H997-H1005.

Seguela P, Wadiche J, Dineley-Miller K, Dani JA, Patrick JW (1993) Molecular cloning, functional properties, and distribution of rat brain $\alpha 7$ : a nicotinic cation channel highly permeable to calcium. J Neurosci 13:596-604.

Selyanko AA, Skok VI (1992) Acetylcholine receptors in rat cardiac neurones. J Auton Nerv Syst 40:33-48.

Smith MA, Margiotta JF, Berg DK (1983) Differential regulation of acetylcholine sensitivity and $\alpha$-bungarotoxin-binding sites on ciliary ganglion neurons in cell culture. J Neurosci 3:2395-2402.

Sucher NJ, Cheng TPO, Lipton SA (1990) Neural nicotinic acetylcholine responses in sensory neurons from postnatal rat. Brain Res 533:248-254.

Ullian EM, McIntosh JM, Sargent PB (1997) Rapid synaptic transmission in the avian CG is mediated by two distinct classes of nicotinic receptors. J Neurosci 17:7210-7219.

Vernallis AB, Conroy WG, Berg DK (1993) Neurons assemble acetylcholine receptors with as many as three kinds of subunits while maintaining subunit segregation among receptor subtypes. Neuron 10:451-464

Zhang Z-w, Feltz P (1990) Nicotinic acetylcholine receptors in porcine hypophyseal intermediate lobe cells. J Physiol (Lond) 422:83-101.

Zhang Z-w, Vijayaraghavan S, Berg DK (1994) Neuronal acetylcholine receptors that bind $\alpha$-bungarotoxin with high affinity function as ligandgated ion channels. Neuron 12:167-177.

Zhang Z-w, Coggan JS, Berg DK (1996) Synaptic currents generated by neuronal acetylcholine receptors sensitive to $\alpha$-bungarotoxin. Neuron 17:1231-1240.

Zorumski CF, Thio LL, Isenberg KE, Clifford DB (1992) Nicotinic acetylcholine currents in cultured postnatal rat hippocampal neurons. Mol Pharmacol 41:931-936. 